\title{
CLINICAL BLADDER CANCER
}




\title{
CLINICAL \\ BLADDER CANCER
}

Edited by

L. DENIS

A. Z. Middelheim

Antwerp, Belgium

P. H. SMITH

St. James University Hospital Leeds, England

\author{
and \\ M. PAVONE-MACALUSO \\ University Polyclinic Hospital \\ Palermo, Italy
}

PLENUM PRESS • NEW YORK AND LONDOY 


\section{Library of Congress Cataloging in Publication Data}

International Symposium on Bladder Cancer (1980 : Antwerp, Belgium) Clinical bladder cancer.

Proceedings of an International Symposium on Bladder Cancer and a selection of urological papers presented at the Antwerp Medical Days, held September 19-20, 1980, in Antwerp, Belgium" - Verso t.p.

The meeting was sponsored by the Antwerp Medical Days Program Committee.

Bibliography: p.

Includes index.

1. Bladder-Cancer-Congresses. I. Denis, L. II. Smith, P. H. (Philip Henry) III. Pavone-Macaluso, M. IV. Antwerp Medical Days Program Committee. V. Title. (DNLM: 1. Bladder neoplasms-Congresses. WJ 504 C641 1980)

RC280.B51527 1980

Proceedings of an international symposium on bladder cancer and a selection of urological papers presented at the Antwerp Medical Days, held September 19-20, 1980, in Antwerp, Belgium

(c) 1982 Plenum Press, New York

Softcover reprint of the hardcover 1st edition 1982

A Division of Plenum Publishing Corporation 233 Spring Street, New York, N.Y. 10013

\section{All rights reserved}

No part of this book may be reproduced, stored in a retrieval system, or transmitted in any form or by any means, electronic, mechanical, photocopying, microfilming, recording, or otherwise, without written permission from the Publisher 
35th ANTWERP MEDICAL DAYS - SEPTEMBER 18 - 20, 1980 INTERNATIONAL SYMPOSIUM "BLADDER CANCER"

Under the auspices of the Honorable A. Kinsbergen, Governor of the Province of Antwerp, the Symposium was organized by THE ANTWERP MEDICAL DAYS.

Program Committee:

L. DENIS President, Vrije Universiteit Brussel

L. EYCKMANS President Elect, Institute of Tropical Medicine, Antwerp

P. NOWE Secretary, A.Z. Middelheim, Antwerpen

Scientific Committee:
P. AUVRAY
President Société Belge d'Urologie
F. EDSMYR
Director World Health Organisation Collaborating Centres for Research and Treatment of Urinary Bladder Cancer
W. GEPTS
Vrije Universiteit Brussel
A. HUBENS Universitaire Instelling Antwerpen
G. PARIZEL Universitaire Instelling Antwerpen
M. PAVONE President EORTC Urological Group
P. SMITH Secretary EORTC Urological Group
K. VAN CAMP President Belgische Vereniging voor Urologie. 


\section{PREFACE}

This volume is a report of the proceedings of an International Symposium on Bladder Cancer and a selection of Urological papers presented at the Antwerp Medical Days in Antwerp, Belgium, on the 19 th and 20th September 1980. The meeting was sponsored by the Antwerp Medical Days Program Committee supported by the Royal Antwerp Circle of Medicine, the Urological Group of the European Organization for Research on the Treatment of Cancer, the Belgische Vereniging voor Urologie, the Société Belge d'Urologie, the Province and City of Antwerp and the National Fund for Scientific Medical Research of Belgium.

Contributors were briefed to avoid too much overlapping, in the hope of obtaining a coherent compilation of clinical data. We are grateful for their discipline which enables early publication.

All the contributions in this volume, except the section on immunology which was selected by the editors for its related interest, were presented at the International symposium under the sections 'Understanding the Disease', 'Therapeutic Approaches'. 'Chemotherapy', and 'Prospective Studies'.

Although the symposium was prepared and the material collected in Antwerp, it is only proper to acknowledge that the correction of the manuscripts and the typing of the material was performed in Leeds. We should particularly like to acknowledge our gratitude to Mrs. S. Conyers, Miss M. Calder, Mrs. S. Purdie and Miss S. Stevenson of the Departments of Urology and Oncology of St. James's University Hospital, Leeds, for their great care and patience in typing this volume and to the Department of Medical Photography at St. James's University Hospital for the preparation of Figures 1, 2, 3 and 4 on pages 129-138. 
CONTENTS

UNDERSTANDING THE DISEASE

Chairman's Summary

$\mathrm{J}$. Auvert

C.K. Anderson

H.J. de Voogt, J.S. Ploem, J.A.M. Brussee, and C.F.H.M. Knepfe

Bladder Tumor - Diagnosis

A. Steg

Staging of Bladder Cancer

M. Pavone-Macaluso

Transurethral Ultrasonography - Bladder Cancer Staging and Other Clinical Application

T. Niijima and S. Nakamura

\section{THERAPEUTIC APPROACHES}

Chairman's Summary

F. Edsmyr

Dynamic Evaluation of Bladder Cancer

G.R. Prout, Jr.

Bladder Cancer - Surgery

W. Vahlensieck 
Radiation Therapy of Carcinoma of the Urinary Bladder

B. Van der Werf-Messing

CHEMOTHERAPY

Chemotherapy for Urinary Bladder Cancer: Developments, Trends, and Future Perspectives

G.H. Jacobi

Intravesical Chemotherapy for Superficial

Bladder Tumors

C.C. Schulman

Progress in the Chemotherapeutic Treatment of Advanced Bladder Cancer

A. Yagoda

\section{IMMUNOLOGY}

Chairman's Summary

J.A. Martinez-Piñeiro

Host Evaluation of Patients with Bladder Cancer

A.T. Lachand and J. Auvert

Chemoimmune Prophylaxis of Superficial

Bladder Cancer

147

H.D. Adolphs and W. Vahlensieck

PROSPECTIVE STUDIES

Chairman's Summary

L. Andersson

Intravesical Chemoprophylaxis of Superficial

Bladder Cancer

H. Rübben and $W$. Lutzeyer

Prospective Studies of the EORTC Urological Group

P.H. Smith

The Philosophy of National Bladder Cancer Project

Studies

G.R. Prout, Jr. 
CONTENTS

List of Contributors

195

Index

199 